\title{
Distinct and yet not Separate: Revisiting the Welfare Models in the EU New Member States
}

\author{
Helena Tendera-Właszczuk, Michał Szymański
}

\begin{abstract}
A B S T R A C T
Objective: The objective of this paper is to evaluate the welfare state models in the EU countries and to start the discussion if the new member states (NMS), i.e. those EU member states that joined the EU in 2004/2007, fit the Sapir typology (Nordic model, Continental model, Anglo-Saxon model, Mediterranean model). The second objective is to examine the labour market situation, reduction of poverty and social inequalities in the EU countries. The third one is to open the issue if the public spending can be managed both justly and effectively.
\end{abstract}

Research Design \& Methods: The linear regression function and correlation has been used to present effectiveness of social expenditures to reduce poverty, as well as evidence that public spending can be managed both justly and effectively.

Findings: This paper demonstrates more similarities can be drawn across the NMS and the EU-15 than within the NMS and EU-15, respectively. The typology of welfare state models is applied to the NMS and their effectiveness is tested. Accordingly, we classify the Czech Republic, Slovenia and Cyprus as countries of the Nordic model; Hungary, Slovakia and Malta as the Continental model; Lithuania, Latvia and Estonia as the Anglo-Saxon model and, finally, Poland, Croatia, Romania and Bulgaria as the Mediterranean model.

Implications \& Recommendations: Recent data suggest that the global crisis has caused an increase in the level of poverty and social spending in the EU countries. However, this is just a temporary situation and it does reflect the solutions of models.

Contribution \& Value Added: The NMS tend to be examined as a separate group of countries that - as the literature suggests - depict different qualities of the welfare models than those pursued in the EU-15.

\section{Article type: research paper}

Keywords: $\quad$ welfare state; European Social Model (ESM); New Member states;

labour market; poverty reduction

JEL codes: $\quad$ D60, D69, F01, F02

Received: 30 October $2016 \quad$ Revised: 16 January $2017 \quad$ Accepted: 30 January 2017

\section{Suggested citation:}

Tendera-Właszczuk, H., \& Szymański, M. (2017). Distinct and yet not Separate: Revisiting the Welfare Models in the EU New Member States. Entrepreneurial Business and Economics Review, 5(1), 131-149, DOI: http://dx.doi.org/10.15678/EBER.2017.050108 


\section{INTRODUCTION}

In the following decades after the Second World War (WW2), the countries of Western Europe have adopted a special socio-economic model, known today as the welfare state or the European Social Model (ESM). The model can be considered as a specific example of social policy implemented in Europe ${ }^{1}$. However, it is worth noting that despite many similarities, over time considerable differentiation within that model of welfare state emerged. The new member states (NMS), i.e. those EU member states that joined the EU in 2004/2007, tend to be examined as a separate group of countries; frequently referred to as the "catching-up countries". In fact, however, as this paper suggests, the NMS cannot be treated as a harmonious group and comparisons should be drawn not within the NMS, but across the NMS and the EU-15. The objective of this paper is to evaluate the welfare state models in the EU countries and to start the discussion if the new member states (NMS), i.e. those EU member states that joined the EU in 2004/2007, fit the Sapir typology (Nordic model, Continental model, Anglo-Saxon model, Mediterranean model). The second objective is to examine the labour market situation, reduction of poverty and social inequalities in the EU countries classified to above mentioned models and to start the discussion on the effectiveness and the social justice of those models. The third one is to open the issue if the public spending can be managed both justly and effectively. The linear regression function and correlation has been used to present effectiveness of social expenditures to reduce poverty, as well as evidence that public spending can be managed both justly and effectively.

The argument is structured as follows. In the first step the basic concepts and definitions pertinent to the question of welfare state models are discussed. Next, the specificities of the different welfare state models that have evolved in the EU-15 are discussed. An assessment of their effectiveness follows. In the fourth part, the typology of welfare state models is applied to the NMS and their effectiveness tested. Conclusions follow.

\section{LITERATURE REVIEW}

\section{Basic Concepts and Definitions}

The ESM is not easy to define as the EU member states have adopted many different variants of the model within their national policy frameworks. This is mainly due to the differences in traditions, cultures, and experiences, as well as the level of economic development across those countries. However, certain similarities among the different national models exist. Consequently, it is possible to propose a general and coherent definition of the ESM by enumerating its most important features.

The Treaty on the functioning of the European Union (TFEU) emphasizes that:

- "In order to promote its overall harmonious development, the Union shall develop and pursue its actions leading to the strengthening of its economic, social and territorial cohesion" (art. 174)

\footnotetext{
${ }^{1}$ For this reason, the terms 'social policy' and the 'European social model' will be used interchangeably.
} 
- "In defining and implementing its policies and activities, the Union shall take into account requirements linked to the promotion of a high level of employment, the guarantee of adequate social protection, the fight against social exclusion, and a high level of education, training and protection of human health" (art. 9)

Other important articles related to the ESM are articles 151-161 of the TFEU, which form part of the chapter on the EU's social policy. The latter outlines the goals of the European social policy, specific areas of activity, and the competences of individual European institutions and member states. Provisions concerning these issues can also be found in the Basic Rights Charter.

In the debate on the ESM several competing standpoints have evolved over time. For instance, Giddens (2006), distinguished the following general features of the ESM: relatively high taxation and wide scope of state interventionism, compulsory and free education, generous welfare system, fight against inequalities. In contrast, Boeri (2002) defines the ESM by reference to labour market protection, limiting poverty and social (income) inequalities, supporting professional activity. From a different angle, Rosati (2009), defines the four main goals of the ESM as follows: full employment and protection against labour market risk, i.e. protection of jobs and worker rights; financial support for those permanently out of the job market or unable to work for reasons such as illness, disability, or age; reduction of social inequalities; universal access to basic social services (education, healthcare, culture).

In order to achieve the above-mentioned objectives, a set of policies and instruments has been introduced across the EU member-states. These include: labour market regulations, incl. minimum wages, working time and conditions, unemployment benefits; social security systems, incl. disability benefits and pensions, other welfare benefits, e.g. family allowances; income redistribution policies, i.e. taxes and money transfers as part of the social security system; free services or services offered at a reduced price, i.e. education, healthcare, culture, leisure (Rosati, 2009). Table 1 presents the general ESM's objectives and instruments of their implementation.

Table 1. ESM's objectives and instruments

\begin{tabular}{|l|l|}
\hline \multicolumn{1}{|c|}{ Objectives } & \multicolumn{1}{c|}{ Instruments } \\
\hline $\begin{array}{l}\text { Employment and protection against labour mar- } \\
\text { ket risk (e.g. decreasing wages or redundancy) }\end{array}$ & Labour market regulations (e.g. labour code) \\
\hline $\begin{array}{l}\text { Ensuring an income for those unfit for work (e.g. } \\
\text { youth, the elderly, the disabled, pregnant mothers) }\end{array}$ & $\begin{array}{l}\text { Social security system (disability pensions, re- } \\
\text { tirement pensions, allowances) }\end{array}$ \\
\hline $\begin{array}{l}\text { Limiting social exclusion, poverty, and reducing } \\
\text { income inequalities }\end{array}$ & $\begin{array}{l}\text { Income redistribution (e.g. progressive taxation, } \\
\text { social transfers) }\end{array}$ \\
\hline Universal access to basic social services & Social service policy (e.g. free education) \\
\hline
\end{tabular}

Source: own elaboration based on (Rosati, 2009).

Undoubtedly, the objectives of the ESM have set the EU member-states distinctly apart from non-members. However, in practice, regardless of the commonalities that the EU members share, substantial differences in how the ESM is implemented across the EU exist. The disparities are related mainly to the instruments of social policy, as well as the detailed objectives and the scope of social security services. There are also differences with respect to the degree of state intervention in the economy, including taxation levels and labour laws. 
The most popular typologies of welfare state are elaborated by Titmuss (1974), Furniss and Tilton (1977). Titmuss distinguished three major models of social policy, including the residual welfare state; the industrial achievement - the performance model; the institutional - redistributive model. Alternatively, Furniss and Tilton have introduced the following typology of welfare state: the positive state; the social service state; the social security state; the social welfare state. Another quite popular typology of welfare state by Esping-Andersen (2010), presented in 1990 makes the distinction between liberal regime, conservative regime, and social democratic regime. Still, it is a rather general typology and it does not account for specific European circumstances. Other classifications have been proposed as well.

Several typologies of the welfare state have been devised and contributed to the debate on regimes: Hall and Soskice (2001), Art and Gelissen (2002), Sapir (2005) have gained particularly wide currency in the academic debate. Sapir distinguished four major models of social policy (ESM) implemented in contemporary Europe, i.e. Nordic, AngloSaxon, Continental and Mediterranean. In this context it is worthwhile to mention that Bonoli (1997), Ferrera (1996) and Leibfried (1993) have also offered insights into social policy models implemented in the South European countries. The Sapir's typology has been chosen for the investigation because Sapir was the first one who applied the general typology of the welfare state regimes to the specific European circumstances.

\section{Features of Welfare State Models as Described by André Sapir}

The Nordic model, often referred to as the social democratic welfare state, is characterized by high levels of taxation, generous benefits, and low income disparities. Labour unions have an important role to play, but the legal protection of employment is relatively moderate. This model allows for the greatest degree of state intervention in social policy. Specialized social security covers basically all types of social risk, and its extent is not dependent on previous income or paid contributions. The Nordic-model countries boast a free education and healthcare system; disability benefits and pensions are available to all citizens without exception. There is a special system of allowances for large families, the disabled, and the elderly. The essence of the Nordic system lies in the assumption that it is primarily the role of the state to ensure social security; the family and the free market are deemed unable to guarantee social welfare. The model aims to provide not only the existential minimum to the poorest, but the most comprehensive assistance possible to all citizens (regardless of their income, health, and life situation); the premise is that every individual has the right to a life on a decently high level. Countries which have adopted this model include Denmark, Sweden, Finland, and the Netherlands (see also Szymański \& Tendera-Właszczuk, 2015).

The Anglo-Saxon model is distinguished by relatively low taxation levels and a social welfare system targeted at the poor and the socially excluded (e.g. the sick and the elderly). The role of labour unions is limited and income stratification relatively high. Public services are underdeveloped and citizens often have recourse to private companies offering social services on the free market, as well as to various foundations and family help. State services are only used as a last resort (Biegański \& Jackowicz, 2008). For this reason, the model bears the hallmarks of the minimal state. It is mainly implemented in Great Britain and Ireland.

The Continental model is an example of a typical welfare state harking back to the Bismarckian solutions of the 19 th century. It is characterized by extensive social security 
services and insurances against all kinds of labour market risk, as well as high and universally available welfare benefits. The income structure is flat and the role of labour unions substantial. The labour market protection is high and its main role is to ensure the employment of people with many years of experience. Compared to the Nordic model, the state offers only modest social services. Moreover, these functions are often taken over by the so-called "third sector", i.e. private companies, foundations, and other non-governmental organizations (Biegański \& Jackowicz, 2008). The Continental model is prevalent in Germany, France, but also in Belgium and Austria.

The Mediterranean model is characterized by an elaborate pension system that allows an earlier retirement than in other models. It is very costly, and, consequently, the source of high public debt. Job protection is high and labour unions play an important role. The primary responsibility of the state is to protect existing employment. Labour market policy seldom takes on an active role. Apart from paying pensions, the state does not actively engage in the benefits and allowances system. Social security allowances, such as unemployment benefits or single-parent benefits, are relatively low. For this reason, an important role in this area is played by non-governmental and religious organizations (mainly the Catholic Church) and the family. This model is typical of Spain, Portugal, Italy, and Greece. According to some sources, some of its elements can also be found in Ireland (Biegański \& Jackowicz, 2008). Table 2 presents the main features of each model. It should be kept in mind, however, that the typology builds on generalizations and hence significant differences can be observed even within individual systems.

There is a tendency in the literature to argue that, of all the models, the Nordic system performs the best in practice. It is both the most effective, as measured by the employment level, and the most socially just, as measured by the percentage of people affected by poverty. There is a tendency in the literature to consider the Mediterranean model as the least effective; it is not only ineffective, but also unjust. The Anglo-Saxon model is described as effective, but not just, and the Continental model as just, but ineffective. The latter two, i.e. the Continental model and the Anglo-Saxon model are treated as intermediate solutions.

Table 2. Social policy models in Western Europe and their main features

\begin{tabular}{|c|c|c|c|c|}
\cline { 2 - 5 } \multicolumn{1}{c|}{} & $\begin{array}{c}\text { Nordic } \\
\text { model }\end{array}$ & Anglo-Saxon model & $\begin{array}{c}\text { Continental } \\
\text { model }\end{array}$ & $\begin{array}{c}\text { Mediterranean } \\
\text { model }\end{array}$ \\
\hline $\begin{array}{c}\text { Labour market } \\
\text { Policy }\end{array}$ & Active & Diversified & Passive & Passive \\
\hline $\begin{array}{c}\text { Employment } \\
\text { protection }\end{array}$ & Moderate & Low & High & High \\
\hline $\begin{array}{c}\text { Income } \\
\text { structure }\end{array}$ & Flat & Diversified & Flat & Flat \\
\hline $\begin{array}{c}\text { Social } \\
\text { welfare }\end{array}$ & Universal & $\begin{array}{c}\text { Limited (mainly the } \\
\text { poor and the sick) }\end{array}$ & Universal & $\begin{array}{c}\text { Limited, mainly } \\
\text { retirement pensions }\end{array}$ \\
\hline $\begin{array}{c}\text { Access to social } \\
\text { services }\end{array}$ & High & Low & Rather high & Medium \\
\hline Taxation & High & Low & Medium/High & Medium \\
\hline
\end{tabular}

Source: own elaboration based on (Rosati, 2009). 


\section{MATERIAL AND METHODS}

\section{Assessment of the Welfare State in EU-15 Countries (2005-2015)}

Rosati (2009) classified the four models in terms of two criteria: social justice and effectiveness. The results of his analysis are shown in Table 3.

Table 3. ESM's effectiveness vs. social justice

\begin{tabular}{|c|c|c|}
\hline Justice/Effectiveness & Low & High \\
\hline High & Continental countries & Nordic countries \\
\hline Low & Mediterranean countries & Anglo-Saxon countries \\
\hline
\end{tabular}

Source: own elaboration based on (Rosati, 2009).

Taking Rosati's typology as a point of departure, we attempted to verify the hypotheses that it (implicitly) entails. To this end, the employment levels and the risk of poverty in each of the EU-15 countries were examined. Then, the data were matched to relevant country groups. In order to make the outcomes of the examination more transparent, the analysis focused not on individual year values of the indicator, which could disrupt the general trend, but on their arithmetical means. For employment, the analysis covered the 2005-2015 period. The poverty level analysis also took account of social transfers (Firure 1).

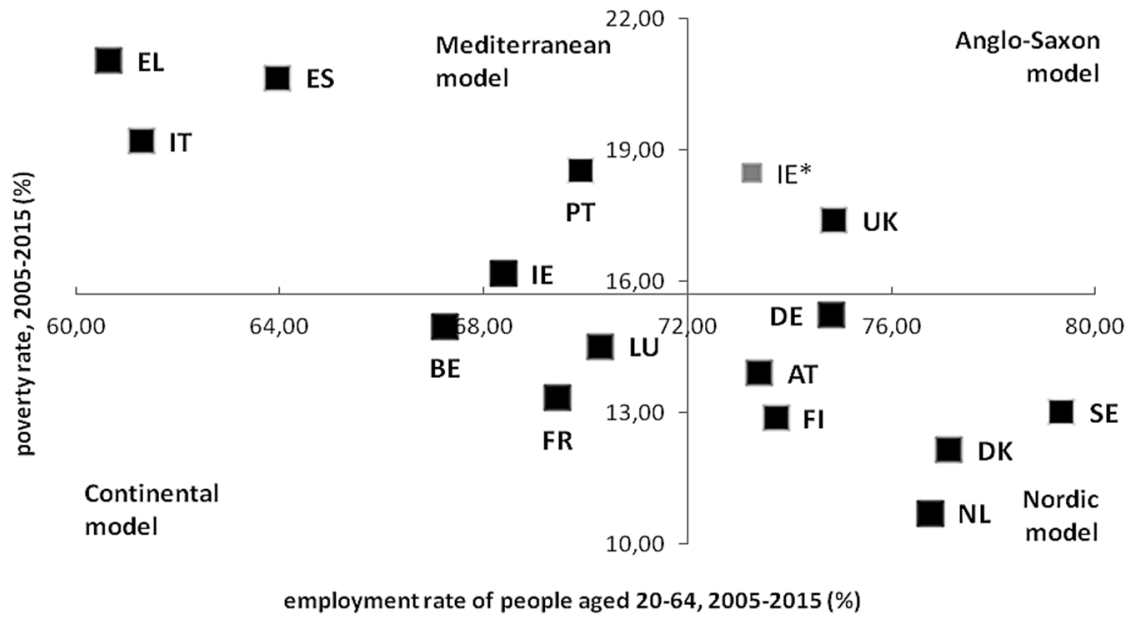

Figure 1. Employment and Risk of Poverty Rates, EU-15

Notes: *Ireland's placement before financial crisis

data for IE: without 2015, data for IT: without 2015, data for LU: without 2015

Source: own calculation based on the Eurostat database:

http://ec.europa.eu/eurostat/tgm/table.do?tab=table\&init=1\&plugin=1\&language=en\&pcode=t2020_10

http://ec.europa.eu/eurostat/tgm/table.do?tab=table\&init=1\&language=en\&pcode=tespm010\&plugin=1

[access: 08.10.2016]

The observations drawn from the examination ${ }^{2}$ confirm that the Nordic countries (the lower right-hand corner) show the best economic and social performance, while the

\footnotetext{
${ }^{2}$ The data presented in the article are not fully comparable, but they include last available data.
} 
Mediterranean countries (the upper left-hand corner) perform the worst. The remaining countries (the upper right-hand and the lower left-hand corner) achieve intermediate results. Simultaneously, the continental countries are more effective at ensuring social justice, while Anglo-Saxon countries lead the way in economic effectiveness ${ }^{3}$.

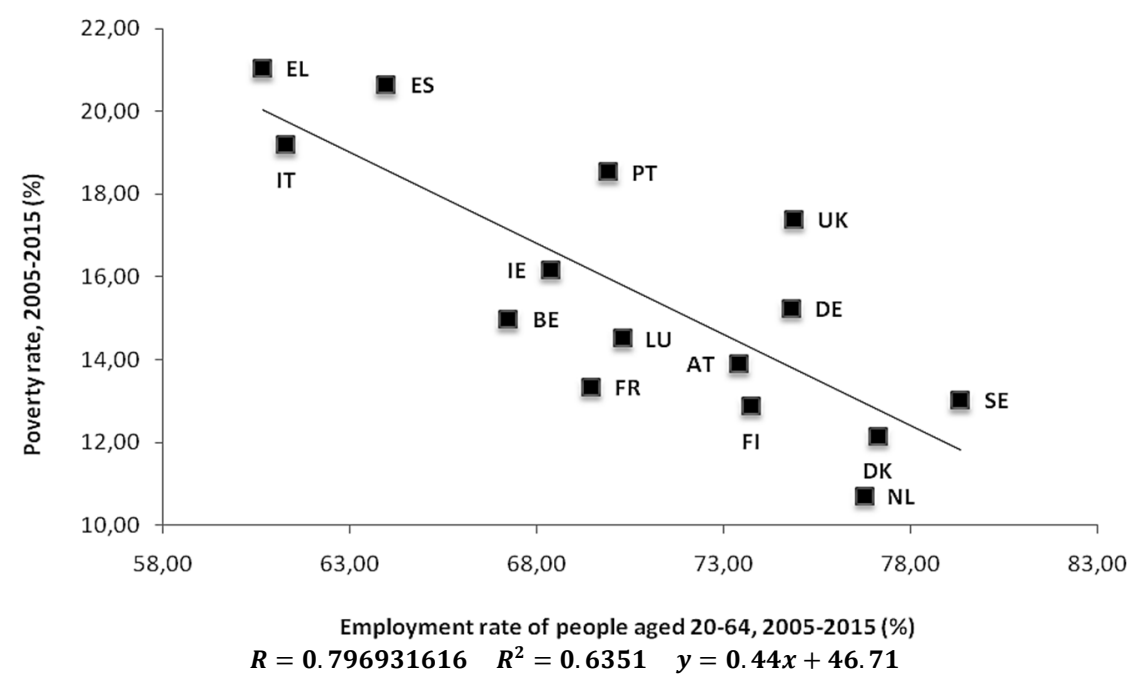

Figure 1a. The negative correlation between Employment and Risk of Poverty Rates, EU-15 Source: as for figure 1.

Figure 1a presents the negative correlation between employment and poverty in the years 2005-2015. The strength of the correlation expressed by R square shows, that the proposed method, linear regression, can be used to start the discussion on the effectiveness and the social justice of those models.

\section{RESULTS AND DISCUSSION}

\section{Classification of NMS According to Sapir's Typology}

There has been a tendency in the literature to regard the NMS as a distinct group of countries. Accordingly, in order to account for the specificity of the NMS and the welfare state models implemented therein, Fenger (2007) added an European postcommunist model of welfare state to Sapir's typology. Indeed, Cerami and Vanhusse (2009) as well as Farkas (2011) suggest that the NMS constitute a separate group in the social policy regimes classification. In fact, we suggest that the NMS cannot be treated as a harmonious, homogeny group of countries.

It should be kept in mind, however, that the point of departure for the welfare state formation process in the post-communist countries was completely different than in

\footnotetext{
${ }^{3}$ It is worth observing that not all the countries could be unequivocally matched to specific models. For Ireland, this is mainly due to the impact of the global crisis. Without the crisis, Ireland would fall within the Anglo-Saxon model. Germany, Austria and Portugal are also problematic; it is assumed that these two countries have partially evolved: the former in the direction of the Nordic, and the latter in the direction of the Mediterranean model. http://www.krakowski.us.edu.pl/?p=ue-06, retrieved on: 26.09.2016.
} 
Western Europe. The historical framework of the welfare state models in the New Member States was extremely important, especially the forty-five years experience of the communist regime and the shift towards the market economy.

The former post-communist countries have not yet fully caught up with the rest of the continent, but the gap has been steadily shrinking. The NMS also represent different approach to social policies. This is due not only to cultural differences, but also to the post-communist point of departure and the specific decisions taken by leading politicians during the transformation period. This suggests that substantial differentiation among the NMS exists. Therefore, it is worthwhile to examine to which extent the NMS fit the Sapir typology, rather than constitute a group of its own.

To this end two indicators listed above have been considered, i.e. employment level and poverty risk. Along these lines, the NMS have been divided into the following four groups of countries: countries with high employment rate and low poverty risk (the Nordic model); countries with low employment rate and high poverty risk (the Mediterranean model); countries with high employment rate and high poverty risk (the Anglo-Saxon model); countries with low employment rate and low poverty risk (the Continental model).

For the post-communist countries, however, the division takes on slightly different values. Due to economic backwardness, economic effectiveness in these countries is lower than in the EU-15 (the vertical effectiveness line moves to the left). The poverty rate division is also less rigorous than for the EU-15 (the horizontal line moves up).

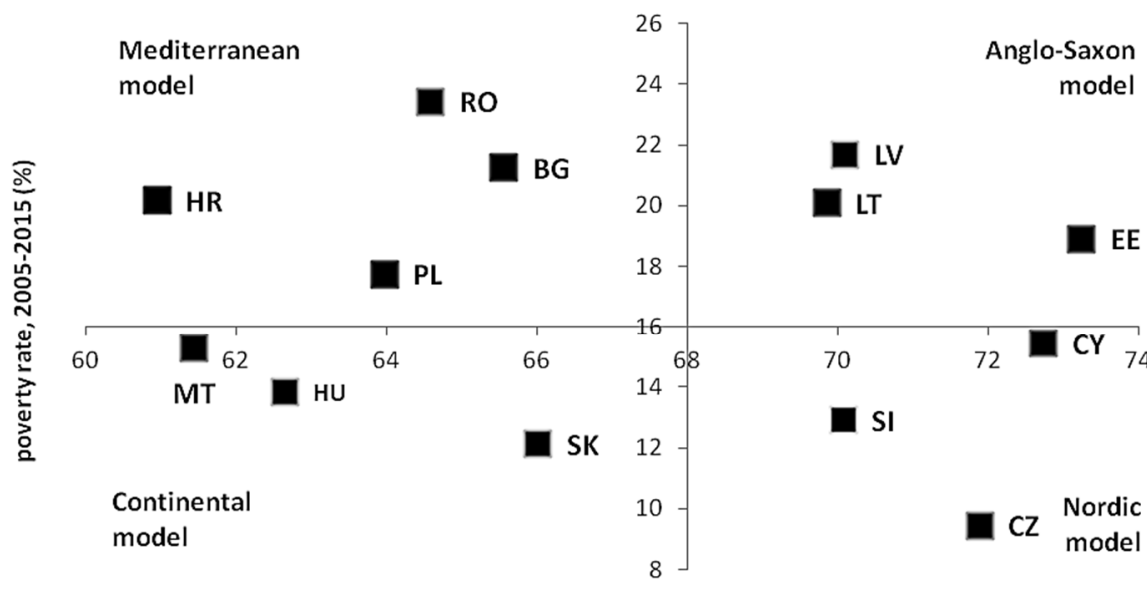

employment rate of people aged 20-64, 2005-2015 (\%)

Figure 2. Employment and Risk of Poverty Rates, NMS

Notes: data for HR: 2010-2014, data for BG: without 2005, data for RO: without 2005 and 2006 Source: own calculation based on the Eurostat database:

http://ec.europa.eu/eurostat/tgm/table.do?tab=table\&init=1\&plugin=1\&language=en\&pcode=t2020_10 http://ec.europa.eu/eurostat/tgm/table.do?tab=table\&init=1\&language=en\&pcode=tespm010\&plugin=1 [access: 08.10.2016 ]

The study shows that the Czech Republic, Slovenia and Cyprus rank highest both in terms of effectiveness and justice. The social models implemented in those countries are characterized by low poverty rate and high employment. Therefore, they fall within the 
Nordic model. The Baltic countries, incl. Lithuania, Latvia and Estonia belong to AngloSaxon model. The employment rate is relatively high and at the same time the poverty rate is high. Slovakia, Malta and Hungary belong to the Continental model. They have a relatively low poverty rate but their employment level is lower than in the Nordic system. Poland, Bulgaria, Romania and Croatia display inferior performance, ranking together with Spain, Italy, and Greece among the countries with the lowest level of economic effectiveness. For this reason, they are included in the Mediterranean model.

\section{Assessment of the Welfare State in the NMS as Compared to the EU-15 Based on Selected Indicators}

The most important index used to measure the level of economic development is the per capita GDP at purchasing power parity. According to Eurostat data ${ }^{4}$, in 2015, the index exceeded the EU average in all the old member states, except Spain, Portugal, and Greece. The NMS were significantly poorer. When examining the different ESM models, it is possible to observe that the per capita GDP is highest in the Nordic model countries (129-108\% of the EU average). As shown before, the continental countries are less effective and the index there stands at $117-106 \%$ of the EU average. Great Britain, the leading example of the Anglo-Saxon model, achieves the per capita GDP of $110 \%$ of the EU average.

The situation of the NMS seems much more instructive to examine. The Czech Republic ranks as the most developed post-communist country (85\%). The dominance of the Nordic model is even more evident in this case; the Czech Republic outranks the poorest EU-15 countries, i.e. Greece and Portugal. It is worth noting that also Slovakia (77\%, Continental model) has already outpaced Greece and caught up with Portugal. Hungary and Poland, representing, respectively, the Continental and the Mediterranean model, achieved the similar index result ( $68 \%$ and $69 \%$ of the EU average). The poorest countries Bulgaria (46\%), Romania (57\%) and Croatia (58\%) represent the Mediterranean model.

The analogy between the old and the new EU countries with regard to their per capita GDP is very strong. It holds not only for the most, but also for the least developed countries.

The presented values of this indicator for separate models are comparable as well. The study also included the HDI values, i.e. the human development index. The goal of the indicator is to neutralize the imperfections of the GDP measure, as the HDI takes into account not only the per capita GDP (at purchasing power parity), but also measures such as life expectancy and education level. Thus, it goes beyond macroeconomic data to focus on the citizens' quality of life.

As it was the case with the GDP, the EU ranking is headed by the Nordic countries. Slovenia and the Czech Republic have significantly outpaced other NMS (as well as some of the EU-15). Continental countries also rank very high. This illustrates the fact that, unlike the GDP measure, where economic effectiveness is paramount, the HDI ranking also gives weight to extra-economic values, which are promoted in the Continental model.

However, it is impossible to conclude that the countries of any one model perform significantly better in this ranking, as was the case with the GDP measure. Alongside Nordic and continental countries, Anglo-Saxon countries, especially Ireland, also rank very high.

\footnotetext{
${ }^{4}$ http://ec.europa.eu/eurostat/tgm/table.do?tab=table\&init=1\&plugin=1\&language=en\&pcode=tec00114, retrieved on 26.10 .2016 .
} 
Table 4. HDI in the EU countries versus welfare state models in 2014

\begin{tabular}{|c|c|c|c|c|}
\hline $\begin{array}{l}\text { Position in the EU } \\
\text { ranking HDI }\end{array}$ & Country & $\begin{array}{c}\text { Position in the } \\
\text { world ranking HDI }\end{array}$ & Scores & $\begin{array}{l}\text { Welfare state mod- } \\
\text { el (by A. Sapir) }\end{array}$ \\
\hline 1 & Denmark & 4 & 0.923 & Nordic \\
\hline 2 & Netherlands & 5 & 0.922 & Nordic \\
\hline 3 & Germany & 6 & 0.916 & Continental \\
\hline 3 & Ireland & 6 & 0.916 & Anglo-Saxon \\
\hline 5 & Sweden & 14 & 0.907 & Nordic \\
\hline 5 & United Kingdom & 14 & 0.907 & Anglo-Saxon \\
\hline 7 & Luxemburg & 19 & 0.892 & Continental \\
\hline 8 & Belgium & 21 & 0.890 & Continental \\
\hline 9 & France & 22 & 0.888 & Continental \\
\hline 10 & Austria & 23 & 0.885 & Continental \\
\hline 11 & Finland & 24 & 0.883 & Nordic \\
\hline 12 & Slovenia & 25 & 0.880 & Nordic \\
\hline 13 & Spain & 26 & 0.876 & Mediterranean \\
\hline 14 & Italy & 27 & 0.873 & Mediterranean \\
\hline 15 & Czech Republic & 28 & 0.870 & Nordic \\
\hline 16 & Greece & 29 & 0.865 & Mediterranean \\
\hline 17 & Estonia & 30 & 0.861 & Anglo-Saxon \\
\hline 18 & Cyprus & 32 & 0.850 & Nordic \\
\hline 19 & Slovakia & 35 & 0.844 & Continental \\
\hline 20 & Poland & 36 & 0.843 & Mediterranean \\
\hline 21 & Malta & 37 & 0.839 & Continental \\
\hline 22 & Lithuania & 37 & 0.839 & Anglo-Saxon \\
\hline 23 & Portugal & 43 & 0.830 & Mediterranean \\
\hline 24 & Hungary & 44 & 0.828 & Continental \\
\hline 25 & Latvia & 46 & 0.819 & Anglo-Saxon \\
\hline 26 & Croatia & 47 & 0.818 & Mediterranean \\
\hline 27 & Romania & 52 & 0.793 & Mediterranean \\
\hline 28 & Bulgaria & 59 & 0.782 & Mediterranean \\
\hline
\end{tabular}

Source: own elaboration based on Human Development Report 2015.

Another important indicator is the Gini index, which represents the degree of social stratification in a given state. The higher the index, the greater the income inequalities in the country. When the index is equal to 1 (which is impossible in practice), it means that all the possible wealth in the country is owned by a single person and the rest have nothing. When it is equal to 0 (which is also impossible), everyone in the country owns the same amount of wealth.

The data show a number of relationships. The highest rate of inequality can be observed in the Anglo-Saxon and the Mediterranean model. This lends support to the earlier research that suggests they are characterized by the lowest level of social justice. Accordingly, the greatest disproportions are attested in Estonia, Latvia, Bulgaria, Lithuania, Cyprus, Spain, Romania, Greece and Portugal. The Gini index there is the highest.

The smallest disproportions are observed in the Nordic and the Continental countries, which supports the earlier conclusion that they show a high level of social 
justice. The Gini index is lowest in Slovenia, the Czech Republic, Sweden, Finland, Belgium, Slovakia, and the Netherlands.

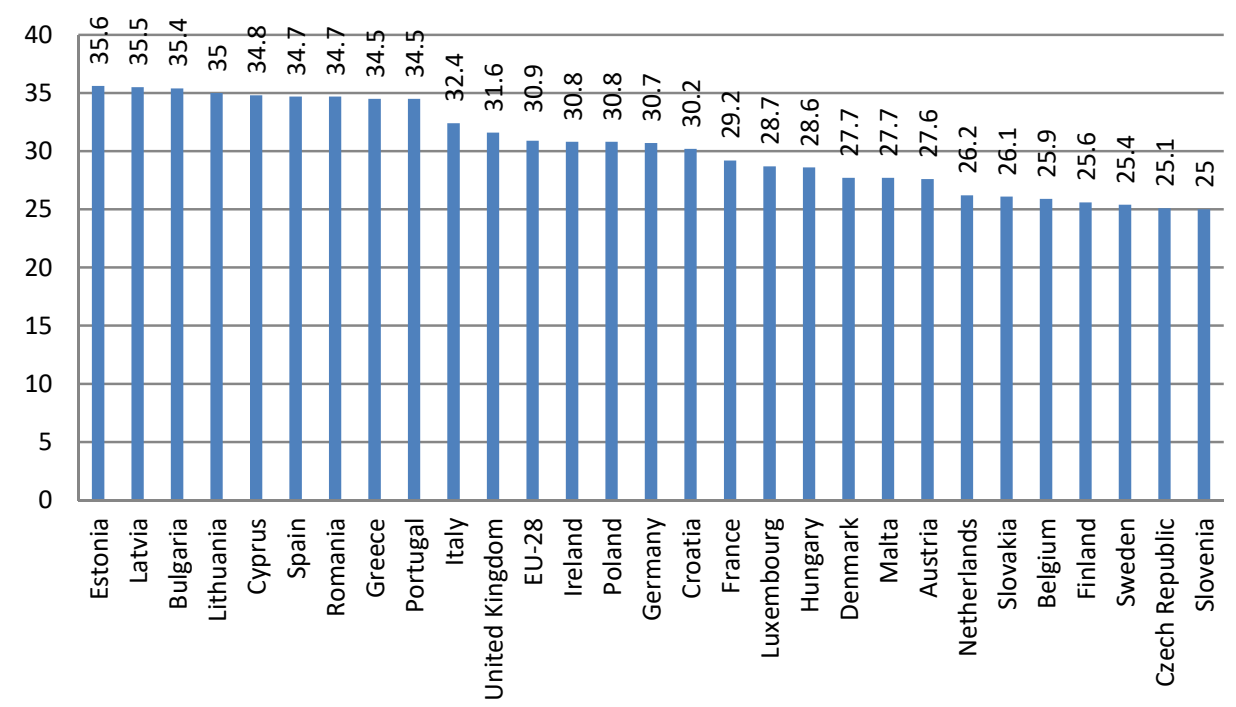

Figure 3. Gini index in the European Union countries in 2014

Source: own calculations based on the Eurostat database:

http://ec.europa.eu/eurostat/tgm/table.do?tab=table\&init=1\&language=en\&pcode=tessi190\&plugin=1 [access: 17.09.2016]

\section{Labour Market Performance}

One of the key issues in the debate about the effectiveness of the European Social Model is the performance of the labour market. Accordingly, the remaining part of the article will attempt to compare the labour market situation across the EU and examine the relationship between the level of employment and the social policy model adopted in each country.

Table 5 shows the unemployment rate across the EU member states. Between 2004 and 2015, the lowest unemployment rate was observed in Luxembourg and Austria (5.1\%), the Netherlands (5.5\%), Denmark (5.8\%), and United Kingdom (6.4\%). The highest unemployment rate was recorded in Spain (17.1\%), Greece (15.8\%) and Slovakia (13.5\%). It is impossible to determine which social policy model brings the best and the worst results, since both groups include countries that belong to at least two different models.

Data on the average unemployment rate among young people (under 25 years old) over the period 2004-2015 was also analysed. Numerous EU countries have had a hard time keeping unemployment low in this age group. Mediterranean countries perform the worst. In Spain and Greece the index stood at $36 \%$ in the analysed period. It was also high for Croatia and Slovakia. It is worth noting that the indicator was high even in Sweden and France. The lowest unemployment rate in the age group was attested in Austria (9.9\%), Germany (10.4\%), Denmark (10.9\%) and the Netherlands (11\%).

It can be concluded that the unemployment rate among the young is lowest in the Nordic countries and highest - in the Mediterranean countries. There are, however, 
certain exceptions to the rule, since the highest-ranking countries also include some Continental states, while Sweden ranks relatively low.

Table 5. The average unemployment rate over the period 2004-2015

\begin{tabular}{|c|c|c|c|}
\hline Country & $\begin{array}{l}\text { The average unem- } \\
\text { ployment rate (\%) }\end{array}$ & $\begin{array}{l}\text { The average youth (aged 15- } \\
\text { 24) unemployment rate (\%) }\end{array}$ & $\begin{array}{l}\text { Welfare state mod- } \\
\text { el (by A. Sapir) }\end{array}$ \\
\hline Luxembourg & 5.1 & 16.8 & Continental \\
\hline Austria & 5.1 & 9.9 & Continental \\
\hline Netherlands & 5.5 & 11.0 & Nordic \\
\hline Denmark & 5.8 & 10.9 & Nordic \\
\hline United Kingdom & 6.4 & 16.8 & Anglo-Saxon \\
\hline Malta & 6.5 & 13.8 & Continental \\
\hline Czech Republic & 6.6 & 16.5 & Nordic \\
\hline Romania & 6.9 & 21.2 & Mediterranean \\
\hline Slovenia & 7.3 & 15.8 & Nordic \\
\hline Germany & 7.4 & 10.4 & Continental \\
\hline Sweden & 7.5 & 22.3 & Nordic \\
\hline Belgium & 8.0 & 21.0 & Continental \\
\hline Finland & 8.1 & 19.8 & Nordic \\
\hline Cyprus & 8.4 & 20.1 & Nordic \\
\hline Hungary & 8.7 & 21.9 & Continental \\
\hline Italy & 8.9 & 29.3 & Mediterranean \\
\hline Estonia & 9.1 & 18.6 & Anglo-Saxon \\
\hline France & 9.2 & 22.5 & Continental \\
\hline Ireland & 9.5 & 19.3 & Anglo-Saxon \\
\hline Bulgaria & 9.8 & 21.1 & Mediterranean \\
\hline Lithuania & 10.6 & 21.0 & Anglo-Saxon \\
\hline Poland & 11.0 & 26.1 & Mediterranean \\
\hline Portugal & 11.5 & 27.6 & Mediterranean \\
\hline Latvia & 11.9 & 21.8 & Anglo-Saxon \\
\hline Croatia & 13.2 & 34.8 & Mediterranean \\
\hline Slovakia & 13.5 & 29.2 & Continental \\
\hline Greece & 15.8 & 36.8 & Mediterranean \\
\hline Spain & 17.1 & 36.5 & Mediterranean \\
\hline
\end{tabular}

Source: own elaboration based on the Eurostat database:

http://ec.europa.eu/eurostat/tgm/table.do?tab=table\&init=1\&plugin=1\&pcode=tipsun20\&language=en $\mathrm{http}: / /$ ec.europa.eu/eurostat/tgm/table.do?tab=table\&init=1\&plugin=1\&pcode=tips/m80\&language=en [access: 17.09.2016]

In terms of unemployment, the Nordic welfare state model appears to perform the best. This stems mainly from the labour market policy adopted in the Nordic countries, i.e. flexicurity. The solution combines labour market flexibility (economic effectiveness) through constructing flexible forms of employment (suited to current labour market needs and the economic situation) and easy hire and fire policies with the guarantee of generous social security benefits (unemployment benefits). An important role in the model is also played by an active labour market policy targeted at unemployed citizens, e.g. skill or career transition trainings (e.g. for older people), loans for the unemployed who wish to start their own enterprise, and subsidized internships and employment 
opportunities for recent graduates entering the job market. These solutions have worked very well in all the Nordic model countries, and especially in Denmark .

As demonstrated in table 6, Denmark has devoted more than $1.5 \%$ of its GDP to the purpose, compared to $1.3 \%$ in Belgium, and $0.8 \%$ in Finland and Sweden. These solutions have been marginal in Great Britain (0.04\%), on Malta $(0,05 \%)$, in Romania $(0,021 \%)$ and Estonia $(0,146 \%)$. An important trend can be seen in the high level of spending on active job market policy in the Nordic countries of the old EU, as well as in Belgium, Ireland, and Spain, even though in the latter two, its share in general labour market policy spending is much lower.

Table 6. Expenditure on labour market in the EU countries in 2011 (\% of GDP)

\begin{tabular}{|c|c|c|c|c|}
\hline Country & Labour market services & $\begin{array}{c}\text { Active labour } \\
\text { market policy }\end{array}$ & $\begin{array}{c}\text { Passive labour } \\
\text { market policy }\end{array}$ & Total \\
\hline Denmark & 0.543 & 1.541 & 1.646 & 3.730 \\
\hline Belgium & 0.212 & 1.379 & 2.091 & 3.682 \\
\hline Finland & 0.124 & 0.857 & 1.475 & 2.456 \\
\hline Sweden & 0.248 & 0.805 & 0.631 & 1.684 \\
\hline Ireland & 0.137 & 0.714 & 2.640 & 3.491 \\
\hline Spain & 0.106 & 0.708 & 2.881 & 3.695 \\
\hline Holland & 0.373 & 0.700 & 1.641 & 2.714 \\
\hline France & 0.252 & 0.682 & 1.402 & 2.336 \\
\hline Austria & 0.186 & 0.571 & 1.286 & 2.043 \\
\hline Luxemburg & 0.053 & 0.459 & 0.638 & 1.150 \\
\hline Portugal & 0.116 & 0.458 & 1.336 & 1.910 \\
\hline Germany & 0.340 & 0.446 & 1.022 & 1.808 \\
\hline Hungary & 0.010 & 0.350 & 0.662 & 1.022 \\
\hline Poland & 0.084 & 0.333 & 0.304 & 0.721 \\
\hline Latvia & 0.036 & 0.332 & 0.318 & 0.686 \\
\hline Cyprus & 0.033 & 0.311 & 0.686 & 1.030 \\
\hline Italy & 0.032 & 0.307 & 1.365 & 1.704 \\
\hline Slovenia & 0.105 & 0.252 & 0.870 & 1.227 \\
\hline Greece & 0.011 & 0.224 & 0.726 & 0.961 \\
\hline Slovakia & 0.072 & 0.223 & 0.496 & 0.791 \\
\hline Lithuania & 0.081 & 0.182 & 0.295 & 0.558 \\
\hline Czech Republic & 0.097 & 0.178 & 0.281 & 0.556 \\
\hline Estonia & 0.082 & 0.146 & 0.492 & 0.720 \\
\hline Bulgaria & 0.039 & 0.050 & 0.422 & 0.593 \\
\hline Malta & 0.112 & 0.021 & 0.321 & 0.483 \\
\hline United Kingdom & 0.341 & 0.027 & 0.303 & 0.684 \\
\hline Romania & 0.247 & 0.295 \\
\hline
\end{tabular}

Source: own elaboration based on Eurostat, Labour market Policy - Expenditure and Participants. Data 2011.

A general conclusion can be drawn that the active labour market policy used in the Nordic countries is much more effective than passive policy, as it effectively reduces unemployment and has a positive impact on employment rate. This is one of the factors which explain the good performance of Nordic labour markets. On the other hand, it must be noted that this is not a universally valid rule (Tendera-Właszczuk et al., 2010). In 2013, 
the employment rate in Belgium was lower by $7 \%$ than in Great Britain, even though the country spent approximately 20 times more of its resources on active employment policy.

\section{Public Spending and the Reduction of Poverty}

Another important issue that deserves attention in context of the discussion on the ESM is the level of public spending in the EU countries. Countries where public spending accounts for the highest percentage of the GDP include the EU-15, especially those of the Nordic and the Continental model. The average public spending in France and Denmark between 2008 and 2015 accounted for $56 \%$ of the GDP and were the highest in the entire European Union. Other countries with high public spending include (Figure 4): Finland (55\%), Belgium and Greece (54\% each). The lowest budget spending was attested in Bulgaria and Romania (38\%), Lithuania and Latvia (39\%) and Estonia (40\%). When data from before the crisis (i.e. the 2000-2007 average) is considered, however, the lowest values are observed for the Anglo-Saxon model, and particularly Ireland (33\% of the GDP) and the Baltic countries (35\%).

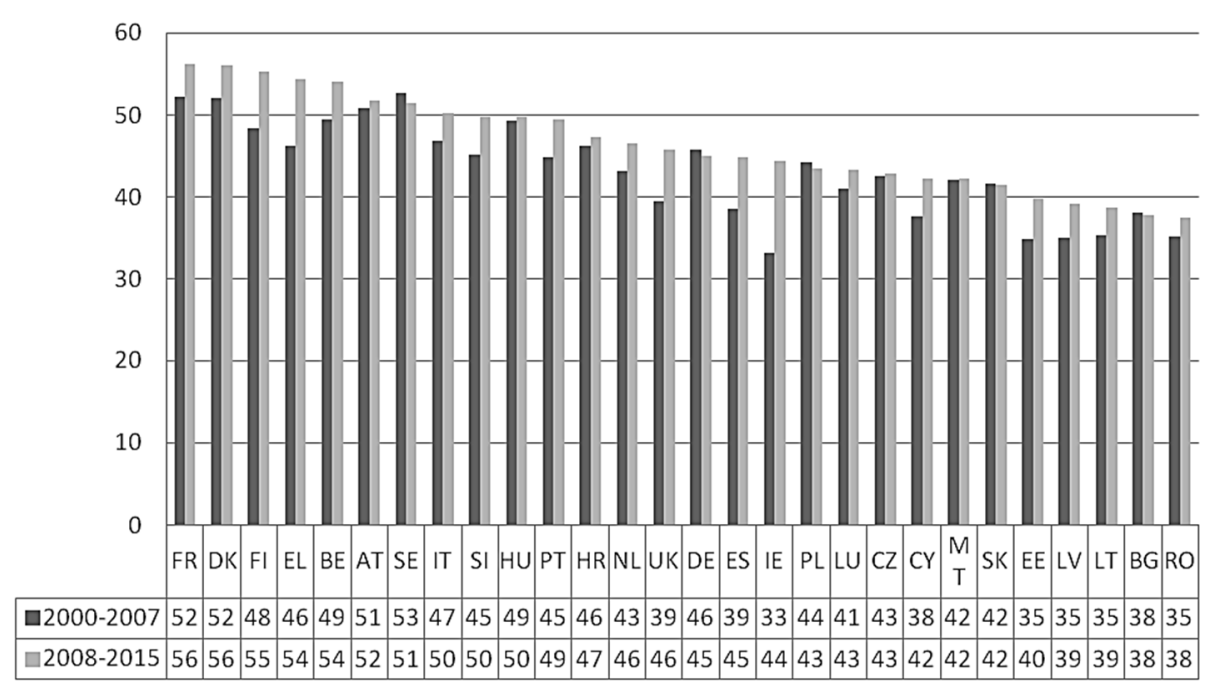

Figure 4. Public spending in the EU countries (average level for 2000-2007 and 2008-2015 as \% of GDP) Source: own elaboration based on the Eurostat database:

http://epp.eurostat.ec.europa.eu/tgm/table.do?tab=table\&init=1\&plugin=1\&language=en\&pcode=tec00023 [access 17.09.2016]

Another important issue of public spending analysis is the share of social expenses in the GDP (Figure 5). Just as above, the greatest spending (in terms of the 2008-2011 average) was recorded in the Nordic countries - Denmark (34\% of the GDP), the Netherlands (31\%), and Sweden (30\%), as well as the Continental countries, such as France, Germany, Belgium, and Austria (more than 30\%). The NMS devoted a much lower share of their GDP to these purposes.

Figure 6 shows the relationship between public spending and the HDI. In the analysed group, a moderate positive correlation $(R=0.519)$ was observed between the two variables; the coefficient of determination was $R^{2}=0.269$. This shows that, to a certain extent, 


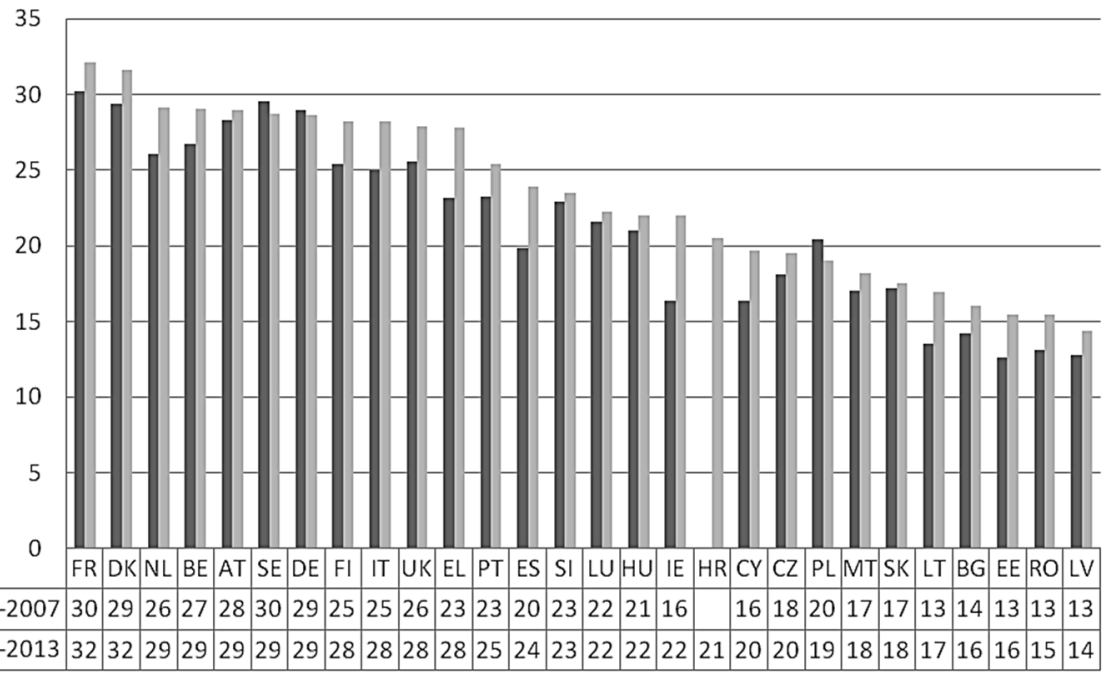

Figure 5. Public spending on social expenses in the EU countries (average level for 2002-2007 and 2008-2013 as \% of GDP)

Notes: data for HR: without 2002-2007, data for EL: without 2013, data for PL: without 2013 Source: own elaboration based on the Eurostat database:

http://epp.eurostat.ec.europa.eu/tgm/table.do?tab=table\&init=1\&language=en\&pcode=tps00098\&plugin=1 [access 17.09.2016]

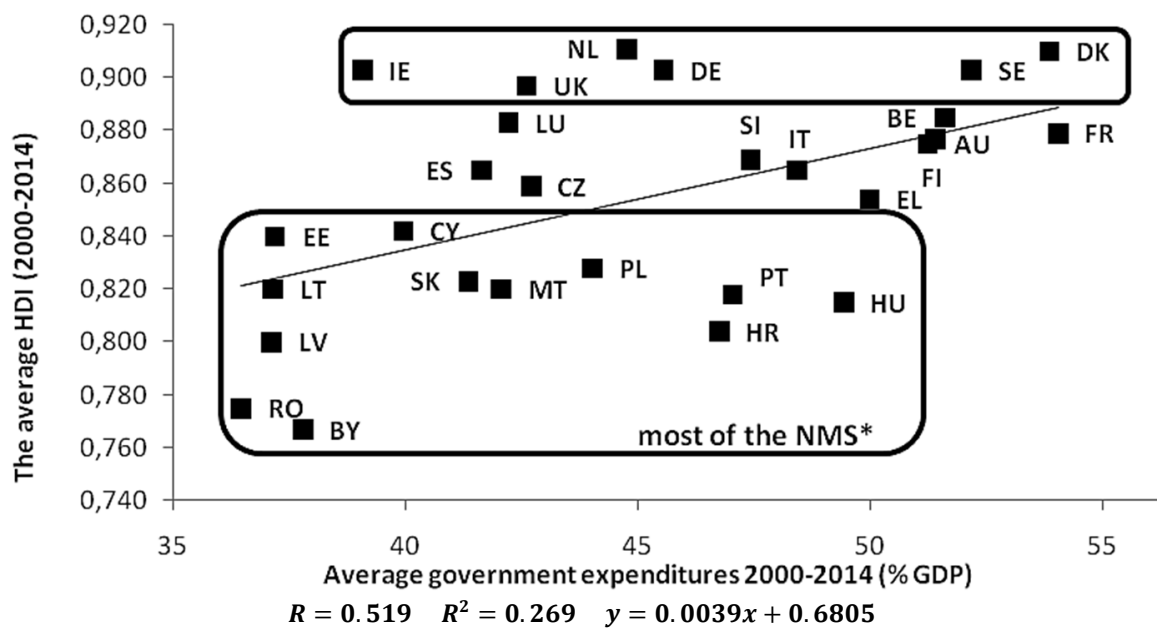

Figure 6. Government Expenditure to Quality of Life, EU-15 and NMS

Notes: *without Slovenia and the Czech Republic, which present a higher rate of socio-economic development, but with Portugal with the lowest socio-economic development in EU-15

Source: own calculations based on data from the Eurostat database and the UN database: http://epp.eurostat.ec.europa.eu/tgm/table.do?tab=table\&plugin=1\&language=en\&pcode=tec00023 http://hdr.undp.org/en/countries [access: 17.09.2016] 
the HDI is determined by the level of public spending - the greater the expenditures, the higher the human development index. However, it should be noted that even though Ireland and Sweden are similar in terms of the human development level measured by the HDI, their public spending policies differ greatly. In recent years (1995-2012), public spending in Ireland accounted, on average, for only $39 \%$ of the GDP ${ }^{5}$, as compared to more than $55 \%$ in Sweden, which suggests that the extra spending in Sweden (a difference of more than 15\%) does not produce desired results. The global economic crisis started in 2007-2008 had a significant influence on the discussed issues.

A moderate positive correlation exists between the amount of social spending and the reduction of poverty $R=0.476$, with the coefficient of determination of $R^{2}=0.227$, which suggests that the countries which spend more reduce poverty to a greater extent than those which spend less. The linear regression function demonstrates that with each $1 \mathrm{pp}$ increase in public spending poverty reduction rise by an average of $0.34 \mathrm{pp}$. It should be noted, however, that it is possible to reduce poverty by as much as the Nordic countries with much less spending in the public sector. A case in point, for instance, is Ireland, which only spent an average of $16 \%$ of its GDP on social purposes over the period 2002-2007, and still recorded a poverty reduction rate of $16 \%$. Similar results (approx. $17 \%)$ were observed only in the Nordic countries, where the average public spending level stood at $30 \%$ of the GDP. Therefore, despite the moderate positive correlation, it is still possible to reduce poverty with a relatively low level of public expenditure. This confirms the law of diminishing returns with regard to the public sector.

Figure 7 presents even more evidence that public spending can be managed both justly and effectively.

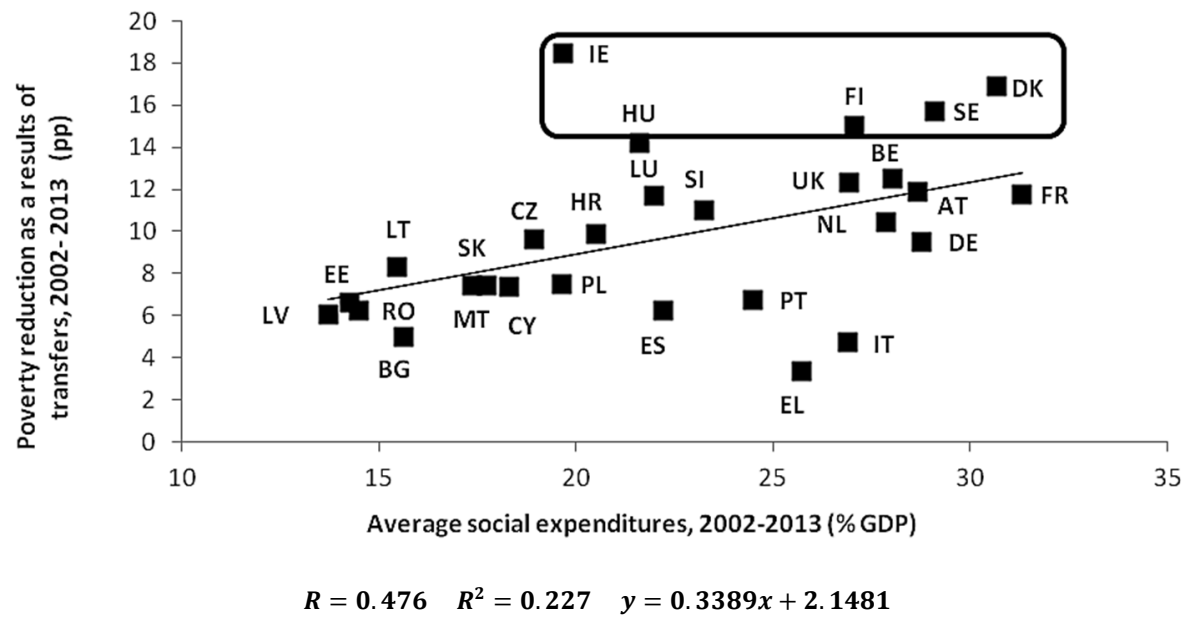

Figure 7. Effectiveness of social expenditures to reduce poverty, EU-15 and NMS Source: own calculations based on data from the Eurostat database:

http://ec.europa.eu/eurostat/tgm/table.do?tab=table\&init=1\&plugin=1\&language=en\&pcode=tsdsc280 http://ec.europa.eu/eurostat/tgm/table.do?tab=table\&init=1\&plugin=1\&language=en\&pcode=tps00098 $\mathrm{http}: / /$ appsso.eurostat.ec.europa.eu/nui/show.do?dataset=ilc_li10\&lang=en [access: 08.10.2016]

\footnotetext{
${ }^{5}$ If not for the crisis, Irish public spending would be even lower and the HDI even higher.
} 


\section{CONCLUSIONS}

The discussion in this paper demonstrates that the Nordic system performs the best among all the welfare state models in terms of the principal assessment criteria that include the labour market situation, as well as the reduction of poverty and social inequalities. However, the Nordic social policy model, based on the assumption that the state is designed not only to preserve, but also to expand the welfare of its citizens, though widely admired, is not without flaws. In theory, the Nordic countries have been successful in reducing poverty. However, their policies have not been very cost-effective; public spending exceeds $30 \%$ of the GDP, and the global crisis has increased it even further. The example of Anglo-Saxon Ireland shows that public expenditure can be used more effectively to fight poverty; Ireland has managed to reduce poverty by almost as much as Sweden, Finland, or Denmark, but at a much lower cost.

It is true that the baseline poverty level (before social transfers) in the Nordic model is lower than in Ireland and that even the high effectiveness of Anglo-Saxon solutions will not succeed in bringing poverty down to a level lower than, for instance, that of Denmark. It is, however, highly probable that at least a partial approximation to the AngloSaxon model could give a boost to economic recovery, and lower taxation would help create new jobs, thus enabling an effective reduction of poverty.

There has been a tendency in the literature to regard the NMS as a distinct group of countries. Some authors suggest that the NMS constitute a separate group in the social policy regimes classification. In fact, we suggest that the NMS cannot be treated as a harmonious, homogeny group of countries. It should be kept in mind, however, that the point of departure for the welfare state formation process in the post-communist countries was completely different than in Western Europe. The historical framework of the welfare state models in the New Member States was extremely important, especially the forty-five years experience of the communist regime and the shift towards the market economy.

The former post-communist countries have not yet fully caught up with the rest of the continent, but the gap has been steadily shrinking. The NMS also represent different approach to social policies. This is due not only to cultural differences, but also to the post-communist point of departure and the specific decisions taken by leading politicians during the transformation period. This suggests that substantial differentiation among the NMS exists.

This paper demonstrates more similarities can be drawn across the NMS and the EU15 than within the NMS and EU-15, respectively. The typology of welfare state models is applied to the NMS and their effectiveness is tested. Accordingly, we classify the Czech Republic, Slovenia and Cyprus as countries of the Nordic model; Hungary, Slovakia and Malta as the continental model; Lithuania, Latvia and Estonia as the Anglo-Saxon model and, finally, Poland, Croatia, Romania and Bulgaria as the Mediterranean model. In the analysis, the NMS, and the Czech Republic (the Nordic model) and Slovakia (the Continental model) in particular, achieve satisfactory results across all indicators.

Today the situation is different. That is, recent data suggest that the global crisis has caused an increase in the level of poverty and social spending in Ireland. However, this is just a temporary situation and it does reflect the solutions of the Anglo-Saxon model. Assuming that all citizens are eligible to receive the benefits of the welfare 
state, it is extremely difficult to keep public spending at a prudent level. A better allocation of capital without compromising the effectiveness of social welfare should be a good solution. It is necessary to further develop this research.

\section{REFERENCES}

Arts, W., \& Gelissen, J. (2002). Three worlds of welfare capitalism or more? A state-of-art report. Journal of European Social Policy, 12(2), 137-158.

Biegański, Z., \& Jackowicz, J. (2008). Unia Europejska - społeczne i gospodarcze aspekty integracji (European Union - social and economic aspects of the integration). Warsawa: Wyższa Szkoła Pedagogiczna w Warszawie.

Boeri, T. (2002). Let Social Policy Models Compete and Europe Will Win. Paper presented at Harvard University, 11-12 April.

Bonoli, G. (1997). Classifying welfare states: A two-dimension approach. Journal of Social Policy, 26(3), 351-372.

Cerami A., \& Vanhusse P. (2009). Introduction. In A. Cerami \& P. Vanhusse (Eds.) Post-Communist Welfare Pathways: Theorizing Social Policy Transformations in Central and Eastern Europe (pp. 73-95). Palgrave Macmillan.

Esping-Andersen G. (1999). Social Foundations of postindustrial economy. New York: Oxford University Press.

Esping-Andersen, G. (2010). Trzy światy kapitalistycznego państwa dobrobytu (The Three Words of Welfare Capitalism). Warszawa: Difin.

Farkas, B. (2011). The Central and Eastern European model of capitalism. Post - Communist Economies, 23( 1), 15-34.

Fenger, H.J.M. (2007). Welfare regimes in Central and Eastern Europe: Incorporating post-communist countries in a welfare regime typology. Contemporary Issues and Ideas in Social Sciences, 3 (2), 1-30.

Ferrera, M. (1996). The "Southern Model “ of welfare in social Europe. Journal of Labor Economics, 5, 17-37.

Furniss, N., \& Tilton, D. (1977). The Case of the Welfare State. Bloomington : Indiana University Press.

Giddens, A. (2006). A Social Model for Europe? Cambridge: Polity Press.

Hall, P.A., \& Soskice, D. (2001). Introduction .In P.A. Hall \& D. Soskice (Eds.), Varieties of capitalism: The institutional foundations of comparative advantage. Oxford: Oxford University Press.

Hemerijck, A. (2002). The self-transformation of the European Social model(s).Oxford: Oxford University Press.

Human Development Report 2015.

Leibfried, S. (1993). Towards a European welfare state. In New perspectives on the welfare state in Europe. London: Routledge.

Rosati, D.K. (2009). Europejski model społeczny. Osiągnięcia, problemy, kierunki zmian. In D.K. Rosati (Ed.), Europejski model społeczny, doświadczenia i przyszłość (pp.26-34). Warszawa: PWE.

Sapir, A. (2005). Globalisation and the Reform of European Social Models. Background document for the presentation at ECOFIN Informal Meeting in Manchester, 9 September 2005.

Szymański, M., \& Tendera-Właszczuk, H. (2015). Realizacja koncepcji państwa dobrobytu w państwach Europy Środkowo-Wschodniej. In H. Tendera-Właszczuk (Ed.), Nowe Państwa Członkowskie w Unii Europejskiej (New Member States in the European Union) (pp. 36-64). Warszawa: Difin.

Tendera-Właszczuk, H., et al. (2010). Polityka społeczna Unii Europejskiej po wschodnim rozszerzeniu (The European Union social policy after the Eastern enlargement). Kraków: PTE.

Titmuss, R. (1974). Social Policy. An Introduction. London: Pantheon Books. 
http://epp.eurostat.ec.europa.eu/statistics_explained/index.php/Glossary:Human_development_i ndex_\%28HDI\%29, retrieved on: 02.09.2016.

http://www.krakowski.us.edu.pl/?p=ue-06, retrieved on: 26.09.2016

\section{Authors}

The contribution share of authors is equal and amounted to $50 \%$ each of them.

\section{Helena Tendera-Właszczuk}

Professor, Jean Monnet ad personam chair, Head of the European Economic Integration Department, Cracow University of Economics. Her research interest include: European economic and political integration, models of integration, governance and stability of the Eurozone, European idea crisis, future of the European integration.

Correspondence to: Prof. dr hab. Helena Tendera-Właszczuk, Cracow University of Economics, Department of European Economic Integration, ul. Rakowicka 27, 31-510 Kraków, Poland, email: tendera@uek.krakow.pl

\section{Michał Szymański}

Graduated from the Faculty of Economics and International Relations at the Cracow University of Economics. His research interests: welfare state models and performance in the EU Member states, Euroscepticism and the future of the European integration.

Correspondence to: Mgr Michał Szymański, Cracow University of Economics, Department of European Economic Integration, ul. Rakowicka 27, 31-510 Kraków, Poland, e-mail: michalszymanski1990@interia.pl

\section{Copyright and License}

This article is published under the terms of the Creative Commons

Attribution - NoDerivs (CC BY-ND 4.0) License

http://creativecommons.org/licenses/by-nd/4.0/

Published by the Centre for Strategic and International Entrepreneurship - Krakow, Poland 
